\title{
$N$-Methylglutamate Dehydrogenase, a Flavohaemoprotein Purified from a New Pink Trimethylamine-utilizing Bacterium
}

\author{
By CHRISTOPHER A. BOULTON, GEOFFREY W. HAYWOOD \\ AND PETER J. LARGE* \\ Department of Biochemistry, University of Hull, Hull HU6 7RX
}

(Received 22 August 1979)

\begin{abstract}
A new strain of pink facultative methylotroph, bacterium AT2, capable of growth on methylamine, trimethylamine, methanol, formate and a range of non- $\mathrm{C}_{1}$ substrates has been isolated. On the basis of the enzyme activities in cell-free extracts, the organism appears to have the same pathway for trimethylamine oxidation as Pseudomonas aminovorans, i.e. via trimethylamine $N$-oxide and $N$-methylglutamate. $N$-Methylglutamate dehydrogenase in this organism was a 'soluble' enzyme (i.e. was not sedimented at $100000 \mathrm{~g}$ in $60 \mathrm{~min}$ ) and reacted with the electron acceptors phenazine methosulphate, 2,6-dichlorophenolindophenol, Wurster's blue and the radical cation of 2,2'-azinodi-[3-ethylbenzthiazoline 6-sulphonate]. It was not active with NAD, ferricyanide or cytochrome $c$. The enzyme was purified to apparent homogeneity (as assessed by polyacrylamide gel electrophoresis) and was shown to contain flavin and cytochrome $c$, both of which could be reduced by $N$-methylglutamate. The flavin prosthetic group could be liberated by boiling and was probably FAD. The true $K_{\mathrm{m}}$ of the enzyme for $N$-methylglutamate was $0.33 \mathrm{~mm}$ and for 2,6-dichlorophenolindophenol, $0 \cdot 20 \mathrm{~mm}$.
\end{abstract}

\section{INTRODUCTION}

$N$-Methylglutamate has been known since 1966 as an early intermediate in the incorporation of methylamine into the cellular constitutents of a number of bacteria (Shaw et al., 1966; Kung, 1969; Trotsenko \& Loginova, 1973; Loginova et al., 1977; Trotsenko \& Loginova, 1978). Hersh et al. (1971) demonstrated in Pseudomonas MA a dehydrogenase catalysing the oxidation of $N$-methylglutamate and postulated that $N$-methylglutamate plays a catalytic role in the oxidation of methylamine to formaldehyde and ammonia, thus:

$$
\begin{gathered}
\mathrm{CH}_{3} \mathrm{NH}_{3}{ }^{+}+\mathrm{L} \text {-Glutamate } \rightarrow N \text {-Methyl-L-glutamate }+\mathrm{NH}_{4}{ }^{+} \\
N \text {-Methyl-L-glutamate }+\mathrm{H}_{2} \mathrm{O}+\text { Acceptor } \rightarrow \text { L-Glutamate }+\mathrm{HCHO}+\text { Acceptor } \mathrm{H}_{2}
\end{gathered}
$$

Evidence supporting this concept has since been reported (Loginova \& Trotsenko, 1974; Loginova et al., 1977; Bamforth \& Large, 1975, 1977a).

$N$-Methylglutamate dehydrogenase [N-methyl-L-glutamate:(acceptor) oxidoreductase (demethylating); EC 1.5.99.5] has been partially purified from Pseudomonas MA (Hersh et al., 1972) and $P$. aminovorans (Bamforth \& Large, 1977a, b). The enzyme in these organisms was membrane-bound, as judged by its sedimentation at $100000 \mathrm{~g}$ and by the requirement for Triton X-100 to solubilize it, and was only active with 2,6-dichlorophenolindophenol (DCPIP), 5-methylphenazinium methylsulphate (phenazine methosulphate, PMS) or cytochrome $c$ as electron acceptors. In contrast, in $P$. methylica (Loginova \& Trotsenko, 1974; Netrusov, 1975), Hyphomicrobium vulgare 3 (Loginova et al., 1977) and H. vulgare ZV (Loginova et al., 1976), $\mathrm{N}$-methylglutamate dehydrogenase failed to sediment at $105000 \mathrm{~g}$ and specifically required NAD as electron acceptor.

We report here the isolation of a new pink bacterium, AT2, which when grown on 
methylamine contains three to four times more $N$-methylglutamate dehydrogenase than is found in $P$. aminovorans. The enzyme in bacterium AT2 does not sediment at $50000 \mathrm{~g}$ and remains mainly in the supernatant after $60 \mathrm{~min}$ at $100000 \mathrm{~g}$, but will not reduce NAD and will use only dyes as electron acceptors. The enzyme has been purified to near homogeneity and we describe the kinetic and spectral properties of the enzyme, which is a flavoprotein containing, or tightly associated with, a $c$-type cytochrome.

\section{METHODS}

Isolation, growth and maintenance of bacterium AT2. The mineral salts medium used for plates during the isolation procedure was salts medium $A$ of Eady et al. (1971) with the addition of $2 \%(\mathrm{~W} / \mathrm{v})$ agar. The carbon sources were added as required, usually at $2 \mathrm{~g} \mathrm{l}^{-1}$. Organic acids were used as their sodium salts, amines as their hydrochlorides. For growth in liquid culture, salts medium B of Eady et al. (1971) was used. In some later experiments bacteria were grown on a medium containing (per litre): $\left(\mathrm{NH}_{4}\right)_{2} \mathrm{SO}_{4}, 1 \mathrm{~g}: \mathrm{MgSO}_{4}$. $7 \mathrm{H}_{2} \mathrm{O}, 0.2 \mathrm{~g} ; \mathrm{NaH}_{2} \mathrm{PO}_{4} \cdot 2 \mathrm{H}_{2} \mathrm{O}, 0.57 \mathrm{~g} ; \mathrm{K}_{2} \mathrm{HPO}_{4}, 1.55 \mathrm{~g}$; trace element solution (Vishniac \& Santer, 1957), $0.2 \mathrm{ml}$; with carbon source as above. Amine hydrochlorides were sterilized by autoclaving, and the remaining substrates were sterilized by filtration using Sartorius $0.45 \mu \mathrm{m}$ membrane filters. Stock cultures of the organism were maintained on salts medium B solidified with agar, with $0.2 \%(\mathrm{w} / \mathrm{v})$ trimethylamine. $\mathrm{HCl}$ as sole carbon source. Cultures of the organism are available from the authors.

Bacteriological tests. These were performed as described by Cruikshank (1965) or Cowan \& Steel (1965).

Preparation of cell-free extracts. Bacterial pellets were suspended in 2 vol. $50 \mathrm{~mm}$-potassium phosphate buffer $\mathrm{pH} 7.0$, cooled to $4{ }^{\circ} \mathrm{C}$ and passed once through a French pressure cell operated at $7.58 \mathrm{MPa}$. The resulting suspension was centrifuged $\left(20 \mathrm{~min}, 50000 \mathrm{~g}, 4^{\circ} \mathrm{C}\right.$ ) and the supernatant was used for enzyme assays.

Enzyme assays. $\mathrm{N}$-Methylglutamate dehydrogenase. Polystyrene cuvettes contained (total volume $3 \mathrm{ml}$ ) $200 \mu \mathrm{mol}$ potassium phosphate buffer $\mathrm{pH} 7 \cdot 0,0 \cdot 17 \mu \mathrm{mol}$ DCPIP, enzyme and water. With crude extracts $3 \mu \mathrm{mol} \mathrm{KCN}$ was also added. After measurement of endogenous dye reduction at $600 \mathrm{~nm}$, the reaction was started by addition of $2 \mu \mathrm{mol} N$-methyl-L-glutamic acid and followed at $25^{\circ} \mathrm{C}$. The reference cuvette contained buffer and enzyme only. One unit of enzyme is the amount required to catalyse the substratedependent reduction of $1 \mu \mathrm{mol}$ DCPIP $\min ^{-1}$ under these conditions.

$\beta$-Galactosidase was assayed by the continuous spectrophotometric method of Wallenfels (1962). The other enzymes used as markers on the Sepharose column were assayed as described in Biochemica Information $(1973,1975)$. The enzymes of $C_{1}$ metabolism (Table 1 ) were assayed by methods already described (Boulton \& Large, 1977; Meiberg \& Harder, 1978).

Purification of $N$-methylglutamate dehydrogenase. Except where indicated, operations were carried out at $4{ }^{\circ} \mathrm{C}$.

Step 1. Preparation of crude extract. Frozen bacteria $(15 \mathrm{~g})$ were suspended in $30 \mathrm{ml} 50 \mathrm{~mm}$-potassium phosphate buffer $\mathrm{pH} \mathrm{7.0}$ and passed once through a French pressure cell at $7.58 \mathrm{MPa}$. The suspension was centrifuged $(30 \mathrm{~min}, 50000 \mathrm{~g})$ and the supernatant was carefully decanted. The pellet was resuspended in $15 \mathrm{ml} 50 \mathrm{~mm}$-phosphate $\mathrm{pH} \mathrm{7.0}$ as before and once more passed through the French pressure cell and centrifuged. The supernatants were combined.

Step 2. Heat treatment. The combined supernatants were heated in a water bath at $50^{\circ} \mathrm{C}$ with constant stirring for $20 \mathrm{~min}$. The precipitate was removed by centrifuging $(30 \mathrm{~min}, 50000 \mathrm{~g}$ ).

Step 3. Streptomycin sulphate treatment. To the supernatant was added $0 \cdot 1 \mathrm{vol} .10 \%(\mathrm{w} / \mathrm{v})$ streptomycin sulphate with stirring. The mixture was centrifuged $(30 \mathrm{~min}, 50000 \mathrm{~g})$ and the precipitate was discarded.

Step 4. Ammonium sulphate precipitation. The supernatant was made $70 \%$ saturated in $\left(\mathrm{NH}_{4}\right)_{2} \mathrm{SO}_{4}$ by slow addition of the solid with stirring. The precipitate was separated by centrifuging ( $30 \mathrm{~min}, 50000 \mathrm{~g}$ ) and redissolved in $5 \mathrm{ml} 50 \mathrm{~mm}$-phosphate $\mathrm{pH} 7.0$.

Step 5. Gel filtration on Sepharose 4B. This material was applied to a column $(100 \mathrm{~cm} \times 2.5 \mathrm{~cm}$ diam. $)$ of Sepharose 4B equilibrated with 10 mm-potassium phosphate $\mathrm{pH} 7.0$ and washed with similar buffer. The enzyme activity appeared in the void volume and all the active fractions were combined. Triton X-100 was then added to a final concentration of $0.05 \%(\mathrm{w} / \mathrm{v})$ and the mixture was stirred for $2 \mathrm{~h}$.

Step 6. DEAE-cellulose chromatography. The combined fractions were applied to a column $(40 \mathrm{~cm} \times 2.5 \mathrm{~cm}$ diam.) of DEAE-cellulose (Whatman DE11) equilibrated with $10 \mathrm{~mm}$-potassium phosphate $\mathrm{pH} 7 \cdot 0$ containing $0.05 \%(\mathrm{w} / \mathrm{v})$ Triton X-100 and the column was washed with similar buffer. The enzyme was then eluted with a linear gradient (10 to $300 \mathrm{~mm}$ ) of potassium phosphate $\mathrm{pH} 7.0$ containing $0.05 \%(\mathrm{w} / \mathrm{v})$ Triton $\mathrm{X}-100$ (gradient volume $400 \mathrm{ml}$ ). The enzyme was eluted at $70 \mathrm{~mm}$-phosphate. The combined active fractions were concentrated to a final volume of about $15 \mathrm{ml}$ in an Amicon model 52 ultrafiltration cell with PM30 membrane. This material was then dialysed for $2 \mathrm{~h}$ against $10 \mathrm{mM}$-phosphate $\mathrm{pH} 7.0$ containing $0.05^{\prime \prime},(\mathrm{w} / \mathrm{v})$ Triton X-100. 
Step 7. Hydroxyapatite chromatography. The enzyme was then applied to a column $(20 \mathrm{~cm} \times 1 \mathrm{~cm}$ diam.) of hydroxyapatite (Bio-Rad Bio-Gel HTP) equilibrated in $10 \mathrm{~mm}$-phosphate $\mathrm{pH} 7.0$ containing Triton and washed with similar buffer. It was eluted with a linear gradient (10 to $150 \mathrm{~mm})$ of potassium phosphate pH 7.0 containing $0.05 \%(\mathrm{w} / \mathrm{v})$ Triton X-100 (gradient volume $100 \mathrm{ml}$ ). The activity peak was eluted at $70 \mathrm{~mm}$. The combined active fractions were concentrated by ultrafiltration as before.

Protein determinations. In the absence of Triton X-100, protein was determined by the Lowry method. In the presence of detergent, the method of Wang \& Smith (1975) or the dye-binding method of Bradford (1976) was used. For the first two methods, the standard was bovine serum albumin. For the dye-binding method, the standard was bovine $\gamma$-globulin, and $0.05 \%(\mathrm{w} / \mathrm{v})$ Triton X-100 was present in all solutions, since Triton decreases the colour yield (Bradford, 1976). The calibration curve in the presence of Triton was linear but $22 \%$ lower than in its absence.

Kinetic experiments. To allow use of a wide range of DCPIP concentrations, glass cuvettes of $2 \mathrm{~mm}$ path length were employed with a reaction volume of $0.5 \mathrm{ml}$. The range of DCPIP concentrations was from 10 to $100 \mu \mathrm{M}$, and of $N$-methylglutamate concentrations from 50 to $1000 \mu \mathrm{M}$. Pure enzyme (435 $\mu \mathrm{g}$ protein) from which Triton X-100 had previously been removed was used.

Removal of Triton $X-100$. Before rate measurements and spectral studies were made with the purified enzyme, Triton X-100 was removed by the method of Holloway (1972) using either Bio-Beads SM-2 or Amberlite XAD-2 polystyrene beads.

Polyacrylamide gel electrophoresis. This was performed in separation gels containing $7 \%(\mathrm{w} / \mathrm{v})$ polyacrylamide, without large pore gels, by the method of Davis (1964), except that the gels and running buffer contained $0.05 \%(\mathrm{w} / \mathrm{v})$ Triton X-100. Activity was detected as described previously (Bamforth \& Large, 1977 a). Haemoproteins were detected on gels with 3,3'-diaminobenzidine (other conditions were as described by Thomas et al., 1976). Sodium dodecyl sulphate (SDS) polyacrylamide gel electrophoresis and pretreatment of the samples were as described by Zahler (1974). In some cases, gels were pre-electrophoresed to remove persulphate. Standard molecular weight proteins for SDS gels were from the Boehringer Combithek kit (cat. no. 15661).

Spectral studies. Absorption spectra were recorded on a Cary $14 \mathrm{UV}$ spectrophotometer using the 0 to $0 \cdot 1$ absorbance slide wire, and fluorescence spectra on a Farrand mark 1 spectrofluorimeter. Fluorescence spectra were recorded on sensitivity range 0.03 and are uncorrected.

Thin-layer chromatography. Silica gel G was used with solvents I (butan-1-ol/water/acetic acid/methanol) and IV (phosphate buffer) of Fazekas \& Kokai (1971).

Molecular weight determination. The molecular weight of the partially purified enzyme (step 5) was determined by the method of Andrews (1970) on a column of Sepharose 4B (void volume $238 \mathrm{ml}$ ) using the following molecular weight standards: lactate dehydrogenase (rabbit muscle, BDH) molecular weight 130000 , pyruvate kinase (rabbit muscle, Sigma) 235000, xanthine oxidase (buttermilk, Sigma) 275000, urease (jack bean, Sigma) $490000, \beta$-galactosidase (Escherichia coli, P-L Biochemicals) 520000, bovine thyroglobulin (Sigma) 670000 . The standards were used internally with 1 unit $N$-methylglutamate dehydrogenase. The column was eluted with $10 \mathrm{~mm}$-potassium phosphate $\mathrm{pH} 7.0$ containing $0.05 \%(\mathrm{w} / \mathrm{v})$ Triton X-100. Proteins were detected by measurement of absorbance at $240 \mathrm{~nm}$ and the enzymes by quantitative assay.

Heat stability experiments. Samples $(0.3 \mathrm{ml})$ of enzyme purified to step 6 were heated in a water bath at the indicated temperature in thin-walled glass tubes. Tubes were removed at the times indicated, chilled in ice and assayed for activity.

Chemicals. $N$-Methyl L-amino acids were obtained from Vega-Fox Biochemicals, Tucson, Ariz., U.S.A. The other materials were from sources described previously (Bamforth \& Large, 1977a). Wurster's blue and the radical cation of 2,2'-azinodi-[3-ethylbenzthiazoline 6-sulphonate] (ABTS) were prepared as described by Duine et al. (1978) from precursors obtained from Sigma.

\section{RESULTS}

\section{Isolation of bacterium AT2}

A pink-pigmented organism was identified as a contaminant on agar plates of Pseudomonas aminovorans growing on trimethylamine as sole carbon source. By repeated picking and restreaking of single colonies on trimethylamine agar, the organism was obtained in pure culture and designated AT2.

The organism is a bacterium with the form of short, motile rods, occasionally occurring in pairs. It is Gram-negative, non-spore forming, oxidase- and catalase-positive and it decolorized litmus milk with no clotting after 1 week. Gelatin stabs were not liquefied, and anaerobic growth on either complex or synthetic media was not detected. On salts medium A, 


\section{Table 1. Activities of enzymes oxidizing $C_{1}$ compounds in bacterium AT2 after growth on methylamine or trimethylamine}

Bacteria were disrupted with the French press and centrifuged at $50000 \mathrm{~g}$ as described in Methods. Enzyme activities were assayed in the supernatant fraction by the methods described by Boulton \& Large (1977) or Meiberg \& Harder (1978). Specific activities are expressed as nmol substrate transformed $\min ^{-1}$ (mg protein $)^{-1}$.

\section{Enzyme}

$N$-Methylglutamate dehydrogenase (EC 1 5.99.5)

Dimethylamine mono-oxygenase (NADPH as electron donor)

(EC 1.14.99.-)

Trimethylamine mono-oxygenase (NADPH as electron donor)

(EC 1.14.13.8)

Trimethylamine- $N$-oxide aldolase (demethylase) (EC 4.1.2.32)

Methylamine dehydrogenase (EC 1.4.99.3)

Dimethylamine dehydrogenase (EC 1.5.99.-)

Trimethylamine dehydrogenase (EC 1 5.99.7)

Formaldehyde dehydrogenase (DCPIP as electron acceptor)

(no EC number)

Formaldehyde dehydrogenase $\left(\mathrm{NAD}^{+}\right.$as electron acceptor, glutathione required) (EC 1.2.1.1)

Methanol dehydrogenase (EC 1.1.99.8)

Formate dehydrogenase ( $\mathrm{NAD}^{+}$as electron acceptor)

(EC 1.2.1.2)

Hydroxypyruvate reductase (EC 1.1.1.29 or 81 )
Specific activity after growth on:

$\begin{array}{rr}\text { Methylamine } & \text { Trimethylamine } \\ 27 & 9 \\ 5 & 58 \\ 2 & 200 \\ 5 & 587 \\ 0 & 0 \\ 0 & 0 \\ 0 & 0 \\ 24 & 22 \\ 0 & 0 \\ 0 & 0 \\ 0 & 43 \\ 39 & 3433\end{array}$

solidified with agar, the organism grew very well with $0.2 \%(w / v)$ concentrations of methanol, ethanol, methylamine. $\mathrm{HCl}$, dimethylamine. $\mathrm{HCl}$, trimethylamine. $\mathrm{HCl}$, diethylamine. $\mathrm{HCl}$, or sodium succinate, lactate or pyruvate. Reasonable growth (up to $50 \%$ of that on methylamine) was also detected on ethylamine, fructose and the sodium salts of fumarate, malate, formate and oxalate. No growth was observed on serine, trimethylamine $N$-oxide, tetramethylammonium chloride, glycine, glucose or the sodium salts of acetate, aspartate or citrate. Growth on nutrient agar was poor. In liquid culture, dimethylamine was only poorly utilized (as with $P$. aminovorans; den Dooren de Jong, 1928). The organism can be clearly distinguished from most pink facultative methylotrophs, since it grows well on trimethylamine, and to prevent possible contamination by such organisms, stock cultures were maintained on trimethylamine agar slopes.

\section{Oxidative properties of intact bacteria}

Washed suspensions of methylamine-grown bacteria readily oxidized methylamine, methanol, formaldehyde and formate, but not dimethylamine, trimethylamine, trimethylamine $N$-oxide, tetramethylammonium chloride or $N$-methylglutamate. Trimethylaminegrown bacteria oxidized mono-, di- and trimethylamine, methanol, formate and formaldehyde, but not tetramethylammonium salts.

\section{Properties of cell-free extracts}

The activities of a number of enzymes involved in the oxidation of $C_{1}$ compounds were determined (Table 1). The organism possesses a similar pattern to $P$. aminovorans in that in the 'soluble' cell fraction there was no detectable methanol, mono-, di- or trimethylamine dehydrogenase activity, while trimethylamine and dimethylamine mono-oxygenases, hydroxypyruvate reductase and trimethylamine- $N$-oxide aldolase (demethylase) were present.

The $N$-methylglutamate dehydrogenase activity was very largely 'soluble', i.e. most of it 
Table 2. Distribution of $N$-methylglutamate dehydrogenase activity in subcellular fractions of various bacteria

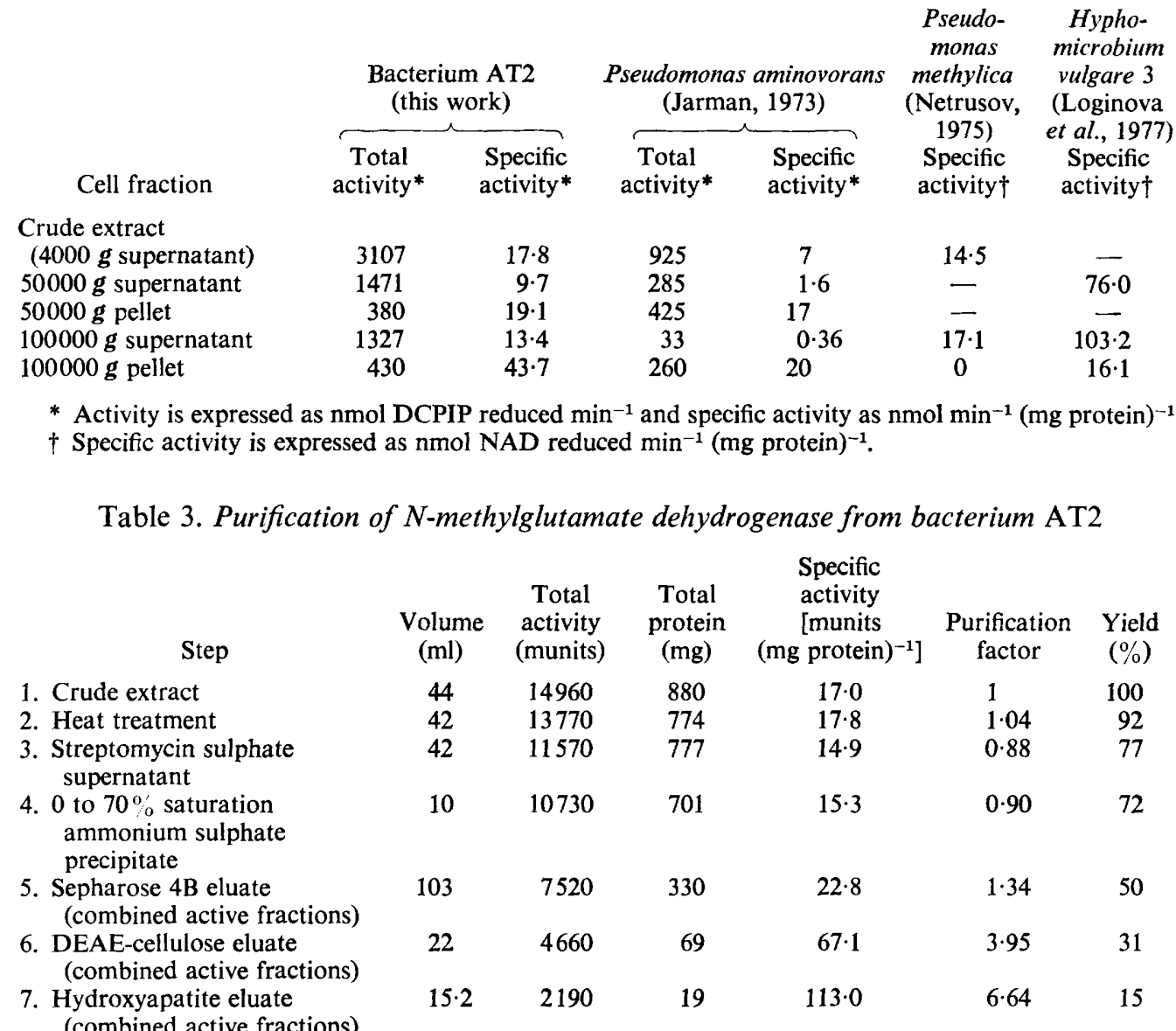

failed to sediment in $1 \mathrm{~h}$ at $100000 \mathrm{~g}$ (Table 2), and it differs in this respect from the enzyme in $P$. aminovorans. Other dehydrogenases were not assayed in the membrane fraction, so it is possible that methanol dehydrogenase was present in this fraction.

\section{Purification of $N$-methylglutamate dehydrogenase}

The purification of $N$-methylglutamate dehydrogenase is summarized in Table 3 . The first four steps were not really purification steps, in that they did not increase the specific activity. The purpose of the heat treatment was to inactivate any more labile enzymes, the streptomycin sulphate removed nucleic acid and the ammonium sulphate precipitation concentrated the enzyme prior to gel filtration. Even the gel filtration only removed lower molecular weight material. It was found that the enzyme was excluded from Sepharose 4B because it aggregated. If Triton X-100 (which presumably disaggregated the enzyme) was added at this stage, recovery of enzyme activity from the two subsequent chromatographic columns was much improved, and its presence made polyacrylamide gel electrophoresis possible, since in the absence of Triton the enzyme failed to enter the separation gel. The two actual purification steps ( 6 and 7 ) resulted in a preparation that was nearly homogeneous on polyacrylamide gel electrophoresis at $\mathrm{pH} 8 \cdot 3$. Some preparations gave a single active band, which coincided with haemoprotein as detected with 3,3'-diaminobenzidine, with additionally a very minor single impurity; others gave up to three bands, each with activity. 
Table 4. Activity of various compounds as electron acceptors for N-methylglutamate dehydrogenase

$\begin{array}{lcccc}\text { Compound } & \begin{array}{c}\text { Wavelength } \\ \text { of assay } \\ (\mathrm{nm})\end{array} & \begin{array}{c}\text { Absorption } \\ \text { coefficient } \\ \left(1 \mathrm{mmol}^{-1} \mathrm{~cm}^{-1}\right)\end{array} & V_{\text {max }} & \begin{array}{c}\text { Apparent } K_{\mathrm{m}} \\ (/ / \mathrm{M})\end{array} \\ \text { DCPIP } & 600 & 20 \cdot 6 & 54 \cdot 7 & 65 \\ \text { PMS (in presence of DCPIP) } & 600 & 20 \cdot 6 & 95 \cdot 2 & 100 \\ \text { Wurster's blue } & 612 & 12 \cdot 0 & 107 \cdot 0 & 15 \cdot 3 \\ \text { Radical cation of ABTS } & 660 & 9 \cdot 1 & 151 \cdot 0 & 63\end{array}$

* Expressed as nmol $N$-methylglutamate oxidized $\min ^{-1}$ (mg protein $)^{-1}$; this corrects for differing stoicheiometry between the one-electron and two-electron acceptors.

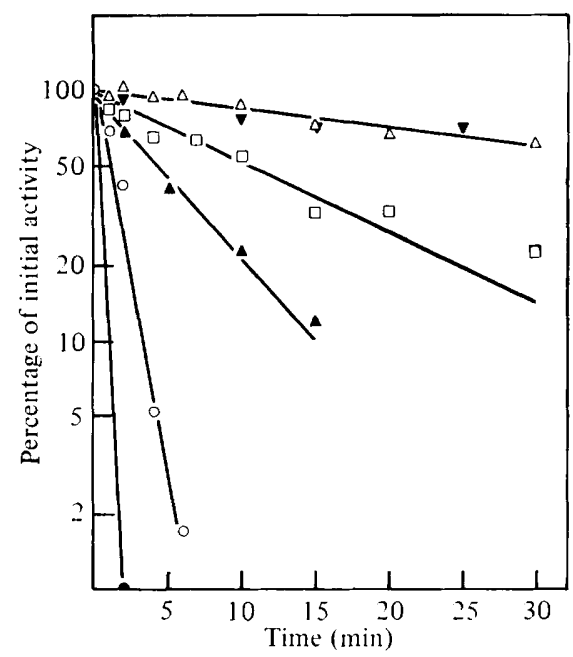

Fig. 1. Comparative heat stability of $N$-methylglutamate dehydrogenases from Pseudomonas aminovorans and bacterium AT2. Samples were treated as described in Methods. Protein concentrations: $P$. aminovorans (solid symbols), $170 \mu \mathrm{g} \mathrm{ml}^{-1}$; bacterium AT2 (open symbols), $480 \mu \mathrm{g} \mathrm{ml}^{\prime}$. Temperatures: $\boldsymbol{\nabla}, 30^{\circ} \mathrm{C} ; \triangle, \Delta, 40^{\circ} \mathrm{C} ; \square, 45^{\circ} \mathrm{C} ; \mathrm{O}, \boldsymbol{O}, 50^{\circ} \mathrm{C}$.

The cause of the mutiple bands is not yet known. On SDS-polyacrylamide gels the preparation gave only a single band, and a comparison of its migration distance with that of proteins of known molecular weight (from the Boehringer Combithek kit) gave a subunit molecular weight for the enzyme of 108000 .

The material was thus, if not completely homogeneous, very nearly so, and hence was suitable for investigation of its spectral properties. Prior to most of the experiments using enzyme of high purity, the Triton X-100 was removed. The material at the end of step 6 was more than $90 \%$ pure and it was used for most of the substrate specificity and kinetic experiments.

\section{Properties of the purified enzyme}

pH optimum. The enzyme had a $\mathrm{pH}$ optimum of $7 \cdot 0$ when either DCPIP alone or DCPIP plus PMS were electron acceptors. This is similar to that observed with the purified enzyme from P. aminovorans (Bamforth \& Large, 1977a).

Substrate specificity. The enzyme was active with the following $N$-methyl amino acids: $N$-methyl-L-glutamate, $N$-methyl-DL-glutamate, $N$-methyl-DL-aspartate, $N$-methyl-DL-alanine, $N$-methyl-L-alanine and sarcosine. No activity could be detected with $33 \mathrm{~mm}-N$-methylD-alanine, in contrast to the $P$. aminovorans enzyme which showed activity with this substrate. When the activity of the enzyme on polyacrylamide gels was tested with the different 

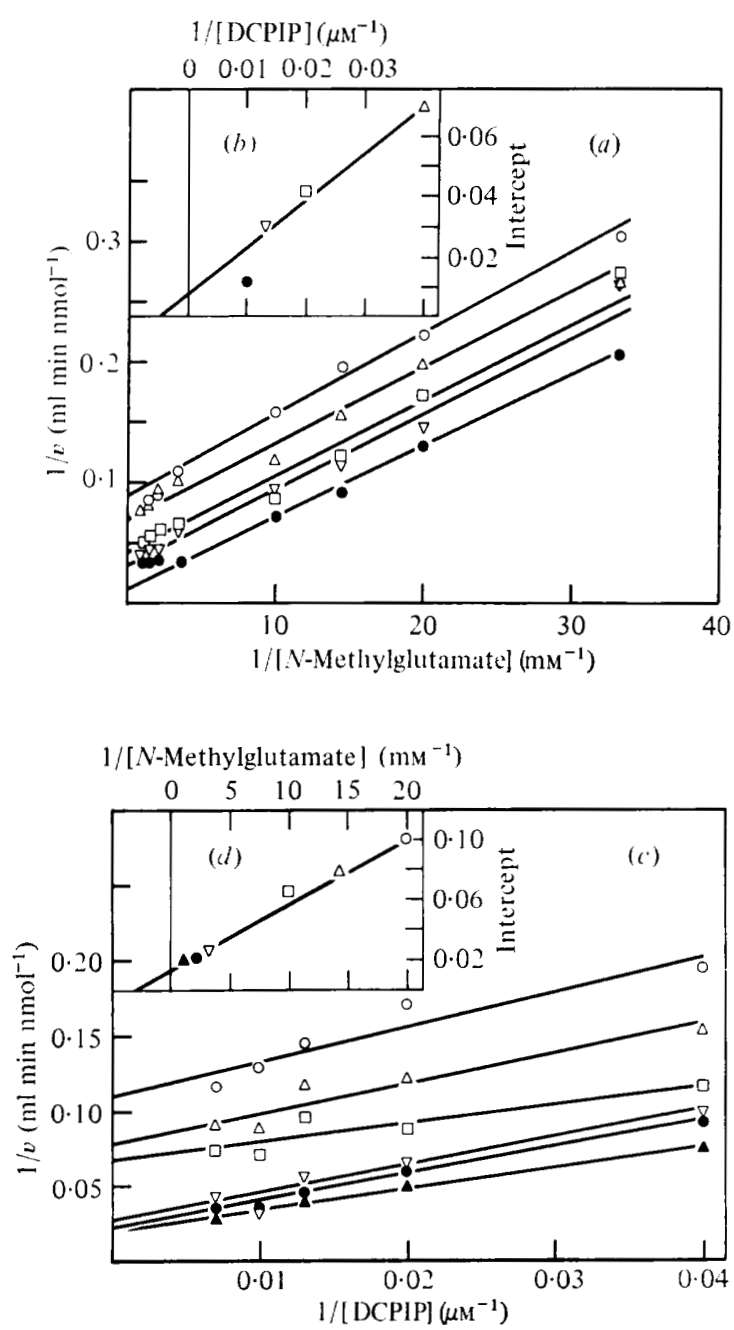

Fig. 2. Primary and secondary double-reciprocal plots relating velocity to substrate concentration for $N$-methylglutamate dehydrogenase. (a) Primary plot of rate and $N$-methylglutamate concentration. Concentrations of DCPIP were: $\bigcirc, 10 \mu_{\mathrm{M}} ; \triangle, 25 \mu_{\mathrm{M}} ; \square, 50 \mu_{\mathrm{M}} ; \nabla, 75 \mu_{\mathrm{M}} ; 0,100 \mu_{\mathrm{M}}$. (c) Primary plot of rate and DCPIP concentration. Concentrations of $N$-methylglutamate were: $0,0.05 \mathrm{~mm} ; \triangle, 0.07 \mathrm{~mm} ; \square, 0.1 \mathrm{~mm} ; \nabla, 0.3 \mathrm{~mm} ; 0,0.5 \mathrm{~mm} ; \Delta, 1.0 \mathrm{~mm}$. Secondary plots: (b) intercepts of the lines in (a) against reciprocal DCPIP concentration; $(d)$ intercepts of the lines in $(c)$ against reciprocal $N$-methylglutamate concentration. The intercepts of the secondary plots on the abscissa give the reciprocal of the true $K_{\mathrm{m}}$ values for the electron donor and acceptor.

substrates, once more no activity was observed with $N$-methyl-D-alanine, while the $N$ methyl L- or DL-amino acids showed a single band of activity at the same $R_{F^{\prime}}$ on each gel. There is thus no likelihood that more than one enzyme active on $N$-methyl amino acids was present in the preparation.

Of the electron acceptors tested, no activity was observed with horse heart cytochrome $c$ (in contrast to the $P$. aminovorans enzyme), NAD (in contrast to the $P$. methylica enzyme) or ferricyanide. The following compounds showed good activity as acceptors: Wurster's blue, the radical cation of ABTS, DCPIP and PMS. Comparison of their $V_{\max }$ values (Table 4) shows that the single-electron acceptors were more effective than the two-electron. acceptors.

Heat stability. The enzyme was more heat stable than the enzyme from $P$. aminovorans 


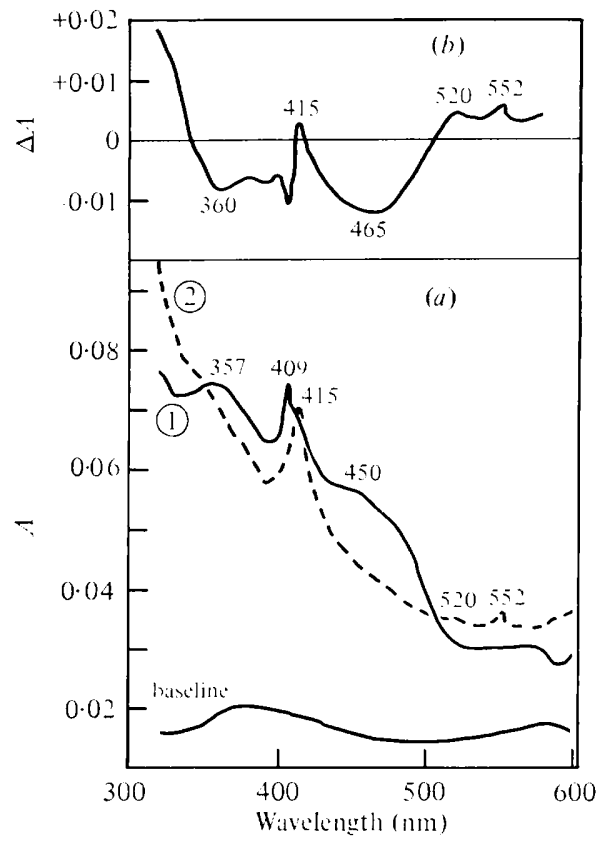

Fig. 3

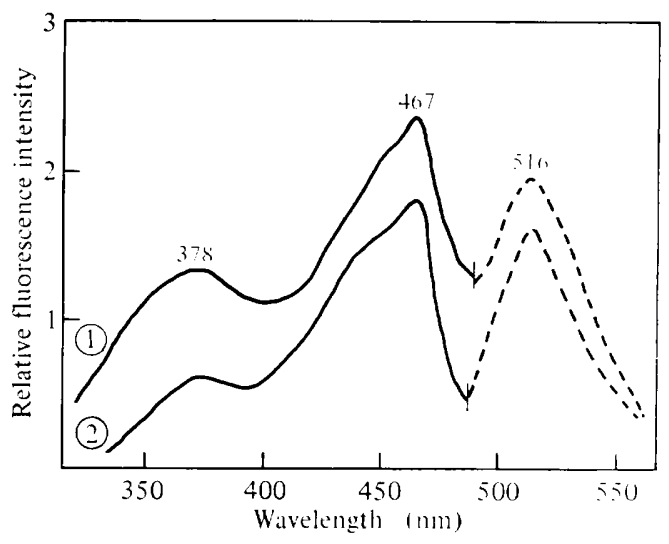

Fig. 4

Fig. 3. Absorption spectrum of homogeneous $N$-methylglutamate dehydrogenase. (a) Absolute spectra: 1 , enzyme as prepared; 2 , enzyme reduced with $1 \mathrm{~mm}-N$-methylglutamate. (b) Difference spectrum, 2 minus 1.

Fig. 4. Fluorescence spectrum of the isolated prosthetic group of $N$-methylglutamate dehydrogenase: - , excitation spectra, fluorescence measured at $520 \mathrm{~nm} ;---$, fluorescence emission spectra. excitation at $450 \mathrm{~nm}$. 1, Prosthetic group, prepared as described in Results. 2, Fluorescence of authentic FAD boiled in the dark for $10 \mathrm{~min}$ with bovine serum albumin and then treated as 1 .

(Fig. 1). The half-life of the purified enzyme was $35 \mathrm{~min}$ at $40{ }^{\circ} \mathrm{C}, 10.5 \mathrm{~min}$ at $45^{\circ} \mathrm{C}$ and about 1 min at $50{ }^{\circ} \mathrm{C}$.

Kinetic properties. Variation of the concentration of $N$-methyl-L-glutamate and DCPIP suggested that the enzyme has Ping Pong type kinetics (Cleland, 1963) (Fig. 2). The true $K_{\mathrm{m}}$ values for the two substrates calculated from these data were $333 \mu \mathrm{M}$ for $N$-methyl-Lglutamate and $200 \mu \mathrm{M}$ for DCPIP. The Ping Pong nature of the reaction was confirmed by examining the effect on the rate of varying the concentration of the two substrates in a fixed ratio ( $1: 1$ in this case). A double reciprocal plot of these data also gave a linear relationship between $1 / v$ and $1 / s$, as is expected for a Ping Pong reaction (Plowman, 1972). The $K_{\mathrm{m}}$ values are similar to those obtained with the $P$. aminovorans enzyme (Bamforth \& Large, $1977 a$ ) except that the $K_{\mathrm{m}}$ for $N$-methylglutamate is slightly higher.

Spectrum. There were changes in the absorption spectrum of the enzyme when $1 \mathrm{~mm}-\mathrm{N}$ methylglutamate was added (Fig. $3 a$ ). The difference spectrum (Fig. $3 b$ ) shows that the broad peaks at 440 to $470 \mathrm{~nm}$ and near $360 \mathrm{~nm}$ were bleached, the peak at $409 \mathrm{~nm}$ shifted to $415 \mathrm{~nm}$ and a new peak appeared at $552 \mathrm{~nm}$. This behaviour suggests the presence of both flavin and $c$-type cytochrome in the purified enzyme. This is in contrast to $P$. aminovorans (Bamforth \& Large, 1977a) where the spectrum of less pure preparations suggested the presence of a $b$-type cytochrome, but since in $P$. aminovorans the cytochrome was not reduced by substrate, it may have been an adventitious contaminant.

Molecular weight. On Sepharose 4B gel filtration in the presence of Triton X-100, the enzyme had a molecular weight of 407000 . Triton is known not to affect the molecular weights of the marker proteins used (Clarke, 1975). 


\section{Properties of the prosthetic group}

Attempts to resolve the enzyme by acidic ammonium sulphate fractionation (Strittmatter, 1961) resulted in an inactive preparation which could not be reactivated by FMN or FAD. The enzyme had a rather feeble fluorescence spectrum, with a very small emission maximum at 507 to $512 \mathrm{~nm}$. Release of a coloured chromophore was achieved by heating the enzyme (previously dialysed against distilled water for $24 \mathrm{~h}$ ) in a boiling water bath for $10 \mathrm{~min}$, taking care to exclude light. The precipitated protein was separated by centrifuging ( $5 \mathrm{~min}$, $5000 \mathrm{~g}$ ). The fluorescence spectrum of the yellow supernatant (Fig. 4) clearly indicated (excitation maxima at 378 and $467 \mathrm{~nm}$ and a fluorescence emission maximum at $516 \mathrm{~nm}$ ) that it contained a flavin derivative and was identical with the fluorescence spectrum of authentic FAD which had been boiled in the presence of bovine serum albumin under the same conditions. The material was taken to dryness under reduced pressure at $25^{\circ} \mathrm{C}$ in the dark. The pale yellow residue was dissolved in water and chromatographed on silica gel $G$ with authentic flavin markers (see Methods). The product had an $R_{F}$ of 0.44 in solvent I and 0.37 in solvent IV. These values suggested that it was neither FMN nor FAD $\left(R_{F^{\prime}}\right.$ values, respectively, 0.20 and 0.32 in solvent $I$ and 0.46 and 0.50 in solvent $I V)$ nor riboflavin ( $R_{F} 0.73$ in solvent $\mathrm{I}$ and 0.33 in solvent IV). However, material purified with a Sep-pak $\mathrm{C}_{18}$ cartridge (Waters Associates) had retention times identical with FAD on liquid chromatography in two different solvent systems (J. A. Duine, J. Frank, Jzn \& P. J. Large, unpublished observations).

\section{DISCUSSION}

The new bacterium differs from the pink bacteria Pseudomonas AM1 and P. methylica in being able to grow on trimethylamine, and in this respect it resembles Pseudomonas 3A2 of Colby \& Zatman (1973). However, although whole cells can oxidize methanol, the organism differs from Pseudomonas $3 \mathrm{~A} 2$ in having no detectable methanol dehydrogenase activity in the 'soluble' cell fraction. It differs from the non-pigmented $P$. aminovorans in lacking an NAD-linked glutathione-dependent formaldehyde dehydrogenase (Boulton \& Large, 1977) and in this respect it resembles Pseudomonas AM1 (Johnson \& Quayle, 1964). It also differs from $P$. aminovorans in that methylamine-grown bacteria contain only very low levels of trimethylamine- $N$-oxide aldolase and dimethylamine mono-oxygenase, both of which are present in high activity in methylamine-grown $P$. aminovorans (Jarman \& Large, 1972; Boulton \& Large, 1979). Nevertheless, the results in Table 1 suggest that bacterium AT2 oxidizes trimethylamine with the intermediate formation of trimethylamine $N$-oxide and $N$-methylglutamate in a similar manner to $P$. aminovorans. (For a scheme showing this pathway, see Boulton \& Large, 1977. For a summary of alternative pathways, see Colby \& Zatman, 1973.) It also seems probable from the high activity of hydroxypyruvate reductase in bacterium AT2 that carbon is assimilated via the serine pathway. Despite its pink pigmentation, the pattern of enzyme activities in bacterium AT2 does not resemble that of Pseudomonas AM1 (which contains a primary-amine dehydrogenase; Eady \& Large, 1968) nor that of $P$. methylica (where an NAD-linked $N$-methylglutamate dehydrogenase is present; Loginova \& Trotsenko, 1974).

Although a number of different organisms are known to contain $N$-methylglutamate dehydrogenases of various types, there appears at present to be no correlation between species or pigmentation of organism and the occurrence of $N$-methylglutamate dehydrogenase, as opposed to the direct oxidation of methylamine via a dehydrogenase or an oxidase (Loginova \& Trotsenko, 1977; Trotsenko \& Loginova, 1978). Nor is there at present any apparent pattern in the occurrence of the different types of $N$-methylglutamate dehydrogenase in various organisms. The resolution of this confused field must await the purification of the unstable NAD-linked enzyme (see below).

$N$-Methylglutamate dehydrogenase of bacterium AT2 differs from the $P$. aminovorans 
enzyme in being 'soluble', i.e. it is not sedimented at $100000 \mathrm{~g}$ in $60 \mathrm{~min}$, and in this respect it resembles the enzymes from P. methylica (Netrusov, 1975), Hyphomicrobium vulgare 3 (Loginova et al., 1977) and H. vulgare ZV (Loginova et al., 1976). However, unlike the latter enzymes it is quite stable and will not use NAD as electron acceptor; it is only active with PMS, DCPIP, Wurster's blue and the radical cation of ABTS. The molecular properties (molecular weight, subunit molecular weight, $K_{\mathrm{m}}$ for electron donor and acceptor, $\mathrm{pH}$ optimum and substrate specificity) resemble fairly closely those of the $P$. aminovorans enzyme (Bamforth \& Large, 1977 $a, b$ ), but the presence of larger amounts of the enzyme in bacterium AT2 (perhaps $15 \%$ of the soluble protein) and the lack of necessity to prepare membrane fractions has enabled us to achieve homogeneity more easily. The enzyme from bacterium AT2 seems to be more stable to heat. The exclusion of the enzyme from Sepharose 4B (exclusion limit $20 \times 10^{6}$ daltons) suggests that in the absence of detergent it aggregates in concentrated solution, a phenomenon characteristic of many membrane proteins (Newby \& Chrambach, 1979; Homcy et al., 1978). Thus it is probably not really very different from the $N$-methylglutamate dehydrogenases of $P$. aminovorans and Pseudomonas MA, which require high concentrations of Triton X-100 to release them into solution. Possibly the AT2 enzyme is less tightly bound, perhaps being an extrinsic rather than intrinsic membrane protein (Singer, 1974). The molecular weight of 407000 taken in conjunction with the subunit molecular weight of 108000 suggest that the enzyme may be a trimer or tetramer (Bamforth \& Large, 1977b) probably occurring in Triton micelles as a single molecule of enzyme per micelle.

The results reported here confirm earlier suggestions that the enzyme is a flavoprotein (Bamforth \& Large, 1977a), and the prosthetic group is not covalently bound, since it can be removed by boiling the enzyme. The flavin is probably FAD. The discovery that the preparation contains substrate-reducible $c$-type cytochrome is novel, although such a prosthetic group has been reported for the amine dehydrogenase of benzylamine-grown $P$. putida (Durham \& Perry, 1978 a, b). Well-characterized enzymes containing both haem and flavin include yeast lactate dehydrogenase (EC 1.1.2.3) (Appleby \& Morton, 1969), spermidine dehydrogenase (EC 1.5.99.-) from Serratia marcescens (Tabor \& Kellogg, 1970) and an oxygen-binding protein from Alcaligenes eutrophus (Probst et al., 1979), although it is noteworthy that all these contain $b$-type cytochromes.

The presence of cytochrome $c$ in $N$-methylglutamate dehydrogenase suggests that this enzyme, and the amine dehydrogenase of $P$. putida (Durham \& Perry, 1978 $a, b$ ), may, like methanol dehydrogenase (O'Keeffe \& Anthony, 1978; Van Verseveld \& Stouthamer, 1978; Netrusov et al., 1977; Bamforth \& Quayle, 1978), feed their electrons into the electron transport chain at the level of cytochrome $c$. It may perhaps also explain why added horse heart cytochrome $c$ is not active as an electron acceptor.

We thank Dr C. W. Bamforth for permission to use some of his unpublished results.

\section{REFERENCES}

ANDREWs, P. (1970). Estimation of molecular size and molecular weights of biological compounds by gel filtration. Methods of Biochemical Analysis 18, $1-53$.

Appleby, C. A. \& Morton, R. K. (1969). Lactic dehydrogenase and cytochrome $b_{2}$ of baker's yeast. Enzymic and chemical properties of the crystalline enzyme. Biochemical Journal 73, 539-550.

Bamforth, C. W. \& LARGe, P. J. (1975). Solubilization and partial purification of $N$-methylglutamate dehydrogenase from Pseudomonas aminovorans. Biochemical Society Transactions 3, 1066-1069.
Bamforth, C. W. \& LARGe, P. J. (1977a). Solubilization, partial purification and properties of $N$ methylglutamate dehydrogenase from Pseudomonas aminovorans. Biochemical Journal 161, 357-370.

Bamforth, C. W. \& Large, P. J. (1977b). The molecular size of $N$-methylglutamate dehydrogenase of Pseudomonas aminovorans. Biochemical Journal 167, 509-512.

Bamforth, C. W. \& Quayle, J. R. (1978). Aerobic and anaerobic growth of Paracoccus denitrificans on methanol. Archives of Microbiology 119, 91-97. 
BiochemiCA INFORMATION (1973, 1975), vols 1 and 2. Mannheim: The Boehringer Corporation.

Boulton, C. A. \& Large, P. J. (1977). Synthesis of certain assimilatory and dissimilatory enzymes during bacterial adaptation to growth on trimethylamine. Journal of General Microbiology 101, 151-156.

Boulton, C. A. \& Large, P. J. (1979). Inactivation of trimethylamine $\mathrm{N}$-oxide aldolase (demethylase) during preparation of bacterial extracts. FEMS Microbiology Letters 5, 159-162.

BRADFORD, M. M. (1976). A rapid and sensitive method for the quantitation of microgram quantities of protein utilizing the principle of protein-dye binding. Analytical Biochemistry 72, 248-254.

Clarke, S. (1975). The size and detergent binding of membrane proteins. Journal of Biological Chemistry 250, 5459-5469.

Cleland, W. W. (1963). The kinetics of enzymecatalysed reactions with two or more substrates or products. II. Inhibition: nomenclature and theory. Biochimica et biophysica acta 67, 173-187.

Colby, J. \& Zatman, L. J. (1973). Trimethylamine metabolism in obligate and facultative methylotrophs. Biochemical Journal 132, 101-112.

CowAN, S. T. \& STEEL, K. J. (1965). Manual for the Identification of Medical Bacteria. Cambridge: Cambridge University Press.

Cruikshank, R. (1965). Medical Microbiology: $A$ Guide to the Laboratory Diagnosis and Control of Infection, 11th edn. Edinburgh: E. \& S. Livingstone.

Davis, B. J. (1964). Disc electrophoresis. II. Method and application to human serum proteins. Annals of the New York Academy of Sciences 121, 404 427.

DEN DOOREN DE JoNG, L. E. (1928). Über protaminophage Bakterien. Zentralblatt für Bakteriologie, Parasitenkunde, Infektionskrankheiten und Hygiene (Abteilung II) 71, 193-232.

Duine, J. A., Frank, J. \& Westerling, J. (1978). Purification and properties of methanol dehydrogenase from Hyphomicrobium X. Biochimica et biophysica acta 524, 277-287.

Durham, D. R. \& Perry, J. J. (1978a). Purification and characterization of a heme-containing amine dehydrogenase from Pseudomonas putida. Journal of Bacteriology 134, 837-843.

Durham, D. R. \& Perry, J. J. (1978b). Amine dehydrogenase of Pseudomonas putida: properties of the heme-prosthetic group. Journal of Bacterio$\log y$ 135, 981-986.

EAdy, R. R. \& LaRge, P. J. (1968). Purification and properties of an amine dehydrogenase from Pseudomonas AM1 and its role in growth on methylamine. Biochemical Journal 168, 245-255.

EADY, R. R., JARMAN, T. R. \& LARGE, P. J. (1971). Microbial oxidation of amines. Partial purification of a mixed-function secondary-amine oxidase system from Pseudomonas aminovorans that contains an enzymically active cytochrome $P-420$ type haemoprotein. Biochemical Journal 125, 449-459.

FazEKAS, A. G. \& KoKaI, K. (1971). Extraction, $F$ purification and separation of tissue flavins for spectrophotometric determination. Methods in Enzymology 18B, 385-398.

Hersh, L. B., Peterson, J. A. \& Thompson, A. A. (1971). An $N$-methylglutamate dehydrogenase from Pseudomonas MA. Archives of Biochemistry and Biophysics 145, 115-120.

Hersh, L. B., Stark, M. L., Worthen, S. \& Fiero, M. K. (1972). N-Methylglutamate dehydrogenase: kinetic studies on the solubilized enzyme. Archives of Biochemistry and Biophysics 150, 219-226.

Holloway, P. W. (1972). A simple procedure for removal of Triton X-100 from protein samples. Analytical Biochemistry 53, 304-308.

Homcy, C., WrenN, S. \& HABER, E. (1978). Affinity purification of cardiac adenylate cyclase: dependence on prior hydrophobic resolution. Proceedings of the National Academy of Sciences of the United States of America 75, 59-63.

JARMAN, T. R. (1973). The enzymic oxidation of primary and secondary amines by Pseudomonas aminovorans. Ph.D. thesis, University of Hull.

JARMAN, T. R. \& LARGE, P. J. (1972). Distribution of the enzymes oxidizing secondary and tertiary amines in Pseudomonas aminovorans grown on various substrates. Journal of General Microbiology 73, 205-208.

Johnson, P. A. \& Quayle, J. R. (1964). Microbial growth on $\mathrm{C}_{1}$ compounds. 6. Oxidation of methanol, formaldehyde and formate by methanol-grown Pseudomonas AM1. Biochemical Journal 93, 281-290.

KUNG, H.-F. (1969). Utilization of one carbon units : metabolism of methylamine by Pseudomonas MS. Ph.D. thesis, Vanderbilt University, U.S.A.

Loginova, N. V. \& Trotsenko, Y. A. (1974). Enzymes of the methanol and methylamine metabolism in Pseudomonas methylica. Microbiology (English translation of Mikrobiologiya) 43, 831-836.

Loginova, N. V. \& Trotsenko, Y. A. (1977). The metabolic pathways of methylated amines in bacteria. In Microbial Growth on $C_{1}$-Compounds, Abstracts of 2nd International Symposium, pp. 37-39. Edited by G. K. Skryabin, M. V. Ivanov, E. N. Kondratjeva, G. V. Zavarzin, Y. A. Trotsenko \& A. I. Nesterov. Pushchino: Scientific Centre for Biological Research.

Loginova, N. V., Shishkina, V. N. \& Trotsenko, Y. A. (1976). Primary metabolic pathways of methylated amines in Hyphomicrobium vulgare. Microbiology (English translation of Mikrobiologiya) 45, 3440.

Loginova, N. V., Shishkina, V. N., Filippova, T. M. \& Trotsenko, Y. A. (1977). Comparative study of the metabolism of methanol and methylamine in Hyphomicrobium vulgare 3. Izvestiva Akademii Nauk SSSR, Seriya Biologischeskaya (English translation) 2, 235-243.

Meiberg, J. B. M. \& Harder, W. (1978). Aerobic and anaerobic metabolism of trimethylamine, dimethylamine and methylamine in Hyphomicrobium X. Journal of General Microbiology 106, 265-276.

Netrusov, A. I. (1975). NAD-dependent $N$-methylglutamate dehydrogenase: a new enzyme of methylamine metabolism in methylotrophs. 
Microbiology (English translation of Mikrobiologiya) 44, 487-488.

Netrusov, A. I., Rodionov, Y. V. \& KondratieVA, E. N. (1977). ATP-generation coupled with $\mathrm{C}_{\mathbf{1}^{-}}$ compound oxidation by methylotrophic bacterium Pseudomonas sp. 2. FEBS Letters 76, 56-58.

Newby, A. C. \& Chrambach, A. (1979). Disaggregation of adenylate cyclase during polyacrylamide-gel electrophoresis in mixtures of ionic and non-ionic detergents. Biochemical Journal 177, 623-630.

O'Keeffe, D. T. \& Anthony, C. (1978). The microbial metabolism of $\mathrm{C}_{1}$ compounds. The stoicheiometry of respiration-driven proton translocation in Pseudomonas AM1 and in a mutant lacking cytochrome $c$. Biochemical Journal 170, 561-567.

Plowman, K. M. (1972). Enzyme Kinetics, p. 50. New York: McGraw-Hill.

Probst, I., Wolf, G. \& Schlegel, H. G. (1979). An oxygen-binding flavohaemoprotein from Alcaligenes eutrophus. Biochimica et biophysica acta 576, $471-478$.

Shaw, W. V., Tsai, L. \& Stadtman, E. R. (1966). The enzymatic synthesis of $N$-methylglutamic acid. Journal of Biological Chemistry 241, 935-945.

Singer, S. J. (1974). The molecular organization of membranes. Annual Review of Biochemistry 43, 805-833.

Strittmatter, P. (1961). The nature of the flavin binding in microsomal cytochrome $b_{5}$ reductase. Journal of Biological Chemistry 236, 2329-2335.
Tabor, C. W. \& Kellogg, P. D. (1970). Identification of flavin adenine dinucleotide and heme in a homogeneous spermidine dehydrogenase from Serratia marcescens. Journal of Biological Chemistry 245, 5424-5433.

Thomas, P. E., LU, A. Y. H., Ryan, D., West, S. B., Kawelex, J. \& LeVin, W. (1976). Multiple forms of rat liver cytochrome $P$-450. Immunochemical evidence with antibody against cytochrome $P-448$. Journal of Biological Chemistry 251, 1385-1391.

Trotsenko, Y. A. \& Loginova, N. V. (1973). The methylamine metabolism of Pseudomonas $\mathrm{sp}$. Microbiology (English translation of Mikrobiologiya) 42, 695-700.

Trotsenko, Y. A. \& Loginova, N. V. (1978). Pathways of metabolism of methylated amines in bacteria. Uspekhi Mikrobiologii (Advances in Microbiology) 14, 28-55. (In Russian.)

VAN Verseveld, H. W. \& Stouthamer, A. H. (1978). Electron-transport chain and coupled oxidative phosphorylation in methanol-grown Paracoccus denitrificans. Archives of Microbiology 118, 13-20.

VishniaC, W. \& SANTER, M. (1957). The thiobacilli. Bacteriological Reviews 21, 195-213.

WALLENFELS, K. (1962). $\beta$-Galactosidase (crystalline). Methods in Enzymology 5, 212-219.

WANG, C.-S. \& SMITH, R. L. (1975). Lowry determination of protein in the presence of Triton X-100. Analytical Biochemistry 63, 414-417.

ZAHLER, W. L. (1974). Analytical polyacrylamide gel electrophoresis and molecular weight determination. Methods in Enzymology 32, 70-81. 